\title{
Gender effects on consumers' symbolic and hedonic preferences and actual clothing consumption in the Czech Republic
}

Article

Accepted Version

Millan, E. and Wright, L. T. (2018) Gender effects on consumers' symbolic and hedonic preferences and actual clothing consumption in the Czech Republic. International Journal of Consumer Studies, 42 (5). pp. 478-488. ISSN 14706423 doi: https://doi.org/10.1111/ijcs.12447 Available at https://centaur.reading.ac.uk/77425/

It is advisable to refer to the publisher's version if you intend to cite from the work. See Guidance on citing.

To link to this article DOI: http://dx.doi.org/10.1111/ijcs.12447

Publisher: Wiley-Blackwell

All outputs in CentAUR are protected by Intellectual Property Rights law, including copyright law. Copyright and IPR is retained by the creators or other copyright holders. Terms and conditions for use of this material are defined in the End User Agreement. 


\section{CentAUR}

Central Archive at the University of Reading

Reading's research outputs online 
Article title: Gender Effects on Consumers' Symbolic and Hedonic Preferences and Actual Clothing Consumption in the Czech Republic

Short title: Gender effects on clothing consumption

\author{
Author Details: \\ Author 1: \\ Department: \\ University: \\ Address:

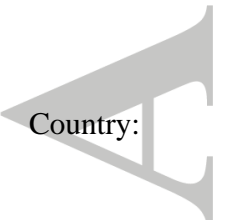 \\ Author 2: \\ Faculty: \\ University: \\ Address: \\ Elena Millan \\ Food Economics and Marketing \\ University of Reading \\ Whiteknights Road \\ PO Box 237 \\ Reading RG6 6AR \\ United Kingdom \\ Len Tiu Wright \\ Business and Law \\ De Montfort University \\ The Gateway \\ Leicester LE1 9BH \\ United Kingdom
}

Corresponding author: Elena Millan

Corresponding Author's Email: elena.millan@reading.ac.uk; Tel.: +44 (0) 1183786193

This article has been accepted for publication and undergone full peer review but has not been through the copyediting, typesetting, pagination and proofreading process which may lead to differences between this version and the Version of Record. Please cite this article as an 'Accepted Article', doi: 10.1111/ijcs.12447 


\title{
Gender Effects on Consumers' Symbolic and Hedonic Preferences and Actual Clothing Consumption in the Czech Republic
}

\begin{abstract}
During the last decade or so consumer products have become more divided by gender than ever before. These changes in marketing practices are likely to introduce, alter or increase any existing gender differences regarding consumers' product preferences and actual consumption. This is a very timely study examining how gender relates to consumers' interest in clothing artefacts and their preferences for the self- and social-symbolic and hedonic meanings of clothing. The influence of gender on actual purchase behaviour towards clothing is also explored. The proposed hypotheses are tested on a large-scale sample of some 1,000+ respondents drawn in the Czech Republic. Using analysis of variance tests, gender differences were found with regard to all but one consumer behaviour phenomenon. No gender effect was found only regarding consumer preference for clothing affiliation symbolism. The study contributes to the theoretical development and empirical evidence in the field of gendered symbolic and hedonic consumption of clothing artefacts. Its findings also suggest possible actions by fashion marketers, as well as some interesting venues for future research.
\end{abstract}

Keywords: Gender effects; Symbolic and hedonic preferences; Actual purchase behaviour; Survey, Clothing 


\section{INTRODUCTION}

Gender has a pervasive influence in our daily lives. Thus, it is not surprising that marketers have long considered gender as an important determinant of consumer behaviour and a key market segmentation variable. What is more, due to the recent changes in marketing practices products are more gendered today than a few decades ago. Even basic functional products, such as toothpaste, a wide range of children's products (e.g., plasters, cough syrup or chocolate eggs), and home repair tools have been designed and marketed with the two genders in mind. These changes are driven by businesses' desire to enhance their brands' appeal, to strengthen market positions in increasingly competitive markets, as well as to charge differential prices and build new revenues (e.g., Worstall, 2016). Several studies have been conducted to date on the effects of gender in the consumption field, covering diverse topics such as gender identity (Borgerson et al., 2006), teenagers' use of product labels (Mangleburg et al., 1997), leisure activities, sex-role portrayals in advertising, and shopping behaviour (see Palan, 2001). In addition, the discourse on the relationship between gender and consumer behaviour, with a special focus on clothing consumption, suggests that gender differences exist with regard to a number of clothing-related phenomena, such as motivation (Workman, 2010), involvement (O'Cass, 2004), decision-making (Coley and Burgess, 2003; Workman and Studak, 2006), and actual purchase behaviour (Peluchette et al., 2006). Undoubtedly, this research stream has generated some interesting insights on gender differences regarding a range of consumer behaviour issues. However, further theoretical work is needed to better understand the gender effects in consumer behaviour in general (Catterall and Maclaran, 2002, p. 406), and the symbolic consumption field in particular. Drawing on various theories and empirical evidence, the present study addresses this knowledge gap in the context of consumer preference for symbolic and hedonic meanings of clothing. Examining this particular gender effect is important given that nowadays symbolic 
and hedonic preferences are main determinants of consumer choices. With the overall satisfaction of their basic clothing needs, consumers have increasingly turned their attention to clothes signifying diverse symbolic and hedonic meanings. Besides, existing theoretical explanations and empirical evidence regarding the relationship of gender with socialsymbolic consumption are not unequivocal. Thus, more research is needed to shed light from both theoretical and empirical perspectives on how gender relates to consumer preferences for symbolic and hedonic meanings. What is more, symbolic and hedonic preferences and higher clothing expenditures have some important managerial implications, which are addressed further below.

Clothing was chosen as the context of the present study because it is a product category that is of value to both male and female consumers. Besides, in addition to its functional role to protect the body, clothing artefacts also perform important symbolic functions, such as signifying gender roles and gender identity (Piaceniti and Mailer, 2004), self-identity (Wee and Ming, 2003), affiliation with important others (Thompson and Haytko, 1997), and social status (Barnard, 2002; Veblen, 1899).

Accordingly, this study pursues the following research objectives: first, to examine the theoretical bases for the assumptions behind how gender differences between male and female consumers affect their interest in clothing, preference for the self-expressive, hedonic, affiliation and status meanings of clothing, and actual purchase behaviour towards clothing (i.e., frequency of clothing shops' visits to see the new arrivals, frequency of clothing purchases, money spent on clothing, and types of clothes bought during an year period); second, to test the developed hypotheses with a national large-scale sample; and third, to identify some useful managerial and research implications arising from the study findings. By exploring these issues, the study contributes to the theoretical development and empirical evidence in the field of gendered symbolic and hedonic consumption, a topic which has been 
previously overlooked. Its findings also suggest possible actions for enhancing marketing effectiveness, as well as some interesting venues for future research.

\section{LITERATURE REVIEW AND HYPOTHESES DEVELOPMENT}

\section{Symbolic and Hedonic Consumption}

From a semiotic point of view, symbolic consumption is an act of communication between the consumer and other members of the society, as well as between the consumer and his/her self (Noth, 1988). Through interpretation or emotion, consumption objects can act as signs that represent something beyond their tangible attributes (Csikszentmihalyi and RochbergHalton, 1981), something that characterises its consumer. Within the discourse on the meanings of possessions as the source of value, Csikszentmihalyi and Rochberg-Halton (1981, p. 27) argue that objects are signs of the qualities of the self, of one's ways of being, feeling, demonstrating "that one is alive, that one matters, that one makes a difference in the world." Building on the body of literature on possession meaning, as well as on own research, Richins (1994) identifies four categories of products' meanings, namely, utilitarian, enjoyment, representation of interpersonal ties, and identity and self-expression. Utilitarian meaning relates to products' usefulness derived from product attributes such as reliability, durability, and price. Enjoyment is associated with products' capacities to evoke pleasurable experiences during consumption and aesthetic contemplation and gratification (Hirschman and LaBarbera, 1990). Representation of interpersonal ties is linked to products that symbolise social relationships such as those with loved ones and close relatives (Noble and Walker, 1997). As vehicles for self-expression, possessions symbolise unique personal qualities, values, and personal history. Possessions can also function as symbols of group membership/identity, social roles, and position in the societal hierarchy (see Dittmar, 1992). 
As noted above, clothing artefacts stand out as one of the most potent signifiers of identity, both personal and social. The symbolic role of clothing relates to what clothing artefacts say about their user, i.e., clothing as a material symbol of individual characteristics, group membership and reference group identification, and social class and status. The hedonic/aesthetic role of clothing relates to its ability to evoke positive feelings and pleasurable experiences (e.g., Barnard, 2002; Holman, 1981).

\section{Gender and Physical Attractiveness}

Within developmental psychology, it has been argued that men's self-definition is largely grounded in their occupation and personal achievement, whereas physical attractiveness is central to a woman's self-concept (see Douvan and Gold, 1966). Consistent with this notion, Cash et al. (2004) and Muth and Cash (1997) report that women view appearance as more important to their personal/social worth and self-concepts than men. Despite having in general better looks than men, women are more concerned with their physical appearance (Franzoi et al., 1990), are less satisfied with their physique (Feingold and Mazzella, 1998), experience greater self-ideal body image discrepancies (Muth and Cash, 1997), and invest greater efforts to keep attractive appearances (Cash et al., 2004). In the consumer behaviour field, Thompson and Haytko (1997, p. 30) found that male consumers are not concerned with the fashion imagery of masculinity depicted in advertising, whereas their female counterparts “interpret fashion's beauty ideals as being far more consequential to their self-identity." Along similar lines, consumer studies on vanity - a fixation on physical appearance and achievement of personal goals - report that women show greater concerns about their physical appearance (Burton et al., 1995; Wang and Waller, 2006; Workman and Lee, 2011). As to the physical-appearance perception component of vanity, some studies report that women perceive their physical appearance in a less positive manner than men (Burton et al., 
1995; Durvasula and Lysonski, 2008), whereas other studies find no gender difference on this vanity attribute (Wang and Waller, 2006; Workman and Lee, 2011).

Why do women place greater importance on physical appearance than men? First, according to the socialisation and social expectancy theories, cultural norms, values and stereotypes favour attractiveness more in females than in males. For many years, culture socialising practices have sensitised both men and women to pay particular attention to women's looks (Marcus and Miller, 2003). Consequently, physical attractiveness has a stronger effect on the traits, self-views and behaviours of female consumers due to the differential judgement and treatment they receive as a function of their attractiveness (Langlois et al., 2000, p. 393). Also, current cultural ideals of beauty place significant emphasis on a slim female physique. The intense exposure to idealised images of beautiful slim female models have raised men's expectations for mating attractive women, with the ensuing effect of weakened men's commitment to their long-term partners (Buss et al., 2001). This weakened commitment additionally motives women to keep attractive appearances for as long as they can. Second, within the social structural perspectives the importance of female physical attractiveness as a mate selection criterion is attributed to the interplay between societal and gender hierarchies, gender roles, and sexual relations (Eagly and Wood, 1999). A woman can improve her rank by marrying a man with high earning capacity (Rabinowitz and Valian, 2000). Hence, women tend to favour high-status mates, whereas men consistently prefer attractive younger women as mates (Geary et al., 2004). Other associations of physical attractiveness, which may result in one's advancement in social hierarchies, are with more favourable judgements, treatment, and behaviour/traits (Hosoda and Coats, 2003). For example, female good looks have been linked to more successful careers (see Netemeyer et al., 1995, p. 624). Third, according to the social role theory, men's greater valuing of a female's physical attractiveness is due to its association with social skills and popularity, 
which are deemed important competences for the performance of female gender roles (Eagly and Wood, 1999). Last but not least, according to the mate-selection theory in evolutionary psychology, traditionally men tend to attach greater importance to women's physical attractiveness relative to other personal qualities because it provides important clues for her health and reproductive potential (Buss, 1999).

\section{Hypotheses}

\section{Gender and Consumer Interest in Clothing}

In view of women's greater concerns with their physical appearance, the centrality of physical appearance in women's self-definition, and the important role of clothing for enhancing one's physical self, female consumers will be more interested in clothing artefacts than their male counterparts. Different socialisation practices for the two sexes are also likely to play a role (Kaiser, 1990). This proposition is supported by previous research (e.g., Peluchette et al., 2006; Weber et al., 2017). During the last few decades, changing social roles and lifestyles have led men, especially younger ones, to form more positive attitudes towards clothing (Cox and Dittmar, 1995; Kaiser et al., 1993). Moreover, contemporary marketing practices have increasingly targeted male consumers, heightening their appearance consciousness, as well as generating social pressures for stronger involvement with appearance enhancing products (McNeill and Douglas, 2011). Nonetheless, due to the more diverse (both internal and external) and stronger pressures on women to maintain attractive looks, their interest in clothing is likely to be more pronounced than that of their male counterparts. Hence, the following hypothesis is proposed:

H1: Relative to men, women have a stronger interest in clothing. 


\section{Gender and Preference for Self-Expressive Meaning}

The importance of physical attractiveness to women and their clothing preferences tend to contribute to their self-images, whereas for men these qualities are largely irrelevant (Spence, 1993, p. 634). Men tend to pursue unique abilities, viewed to be instrumental for gaining more power and status, whereas women tend to pursue uniqueness in physical appearance as a way to social acceptance (Baumeister and Sommer, 1997) and social advancement. What is more, given the importance of finding the right partner, procreation and adequate provision for their offspring amongst their life goals, and the strong competition amongst women to draw the attention of the more eligible, higher-status bachelors, women are likely to use clothing as a strategic means to stand out from the female competition to attract the perfect partner and to keep him in the long run. Therefore, the following hypothesis is proposed:

H2: Relative to men, women have a stronger preference for the self-expressive meaning of clothing.

\section{Gender and Preference for Hedonic Meaning}

This study also argues that women show a stronger preference for the hedonic meaning of clothing than men. Female clothing is more ornamented, aesthetically pleasing and varied in assortment and style, whereas male attire is generally more frugal, sober and understated (Baumeister and Sommer, 1997). Therefore, female clothing may be a greater source of hedonic pleasure than male clothing. Besides, the aesthetic properties of female clothing can enhance women's physical appearance, make them feel better about themselves and boost their attractiveness and self-esteem. What is more, women use their purchases to a greater extent than men to manage their mood, i.e., as retail therapy to engender positive emotions and to reduce stress levels in their daily lives (Coley and Burgess, 2003). Such behaviour 
often happens in the context of clothing. Workman and Studak (2006), for example, report that women are more likely to espouse a desire-based approach to fashion problem recognition, whereas men tend to adopt a need-based fashion problem recognition style. This discussion leads to the following hypothesis:

H3: Relative to men, women have a stronger preference for the hedonic meaning of clothing.

\section{Gender and Preference for Affiliation Meaning}

The relationship between gender and preference for affiliation meaning of clothing is not unequivocal. On the one hand, according to the social role theory, women's greater involvement with domestic and childrearing tasks fosters communal behaviours, whereas men's greater focus on the provider role favours agentic behaviours (Eagly et al., 2000, p. 126). Within the psychology literature on gender differences in self-conceptions it has been argued that men tend to construct an independent self-construal characterised as being autonomous and independent (Markus and Kitayama, 1994), whereas women tend to construct an interdependent self-construal, which emphasises relationships with close others, interdependencies, "obligations to others and responsiveness to the needs of others" (Cross and Madson, 1997, p. 7). Hence, women may draw more heavily than men on the affiliation symbolism of clothing to nurture harmony and belongingness with important others. Some insights into this gender effect come from studies on valued material objects, which report that men and women value different objects, and that the reasons for cherishing objects also vary across the two genders (Csikszentmihalyi and Rochberg-Halton, 1981; Dittmar, 1992; Wallendorf and Arnould, 1988). A common finding of these studies is that men place greater 
importance on objects with instrumental value, whereas women favour more objects signifying interpersonal ties.

However, the effect of any stronger conformity tendencies amongst female than male consumers on their preference for affiliation symbolism could be offset by females' stronger desires for self-expression and their drive to stand out of the female competition. Their generally stronger interest in the latest fashion styles, the acquisition of which allows them the possibility to stand out instead of to blend in, further supports this notion. Another argument developed in the psychology field is that "the need to belong is a powerful, fundamental, and extremely pervasive motivation” (Baumeister and Leary, 1995, p. 497), which is of equal importance to both genders. According to Baumeister and Sommer (1997), the main difference between women and men with regard to their need to belong and how they relate to others is the sphere, in which the need operates: women interact with and invest in a small number of close intimate relations (e.g., family, close friends), whereas men build relationships with a larger number of people from broader social networks.

In view of the above discussion, a directional hypothesis cannot be advanced. Hence, the following null hypothesis is proposed:

H4: There is no significant difference between male and female consumers regarding their preference for the affiliation meaning of clothing.

\section{Gender and Preference for Status Meaning}

Some controversies also exist with regard to the relationship between gender and preference for status meaning of clothing. One possibility is that men are more attentive to clothing status symbolism than women. In general, men place greater importance on status and devote more time and energy to achieve and enhance their status than women (Huberman et al., 
2004). Similarly, studies on gender variations in value priorities indicate that men are more concerned with power, status, and achievement, whereas women place greater importance to benevolence values related to preserving and enhancing the welfare of people to whom one is close (Burgess and Steenkamp, 1998; Macrae et al., 1996). Men's greater concern with power and status may result in a stronger preference for material status markers relative to women. It should be noted that the literature on vanity reports some mixed results with regard to gender effects on professional achievement concern. Contrary to prior expectation, Wang and Waller (2006) and Durvasula and Lysonski (2008) found no gender difference on achievement concern, whereas in Workman and Lee's (2011) study women scored higher than men on this vanity component. Within the evolutionary perspective on human mating it is argued that men use more frequently conspicuous display of economic resources than women because women tend to appreciate them more when selecting their partner ( $\mathrm{Li}$ and Kenrick, 2006). Consistent with this notion, Griskevicius et al. (2007) report that young American males exhibit stronger preference for spending conspicuously on products and services that signal financial resources, such as new car, new watch, and new cell phone. Similarly, Browne and Kaldenberg (1997) found that men scored higher than women on the success dimension of Richins and Dawson's (1992) materialism scale.

However, certain drivers may induce women's stronger preference to status consumption. To start with, women may use status goods as markers of their enhanced social worth in terms of political, economic, occupational, individual, and relational powers gained during the last few decades (Diekman et al., 2004). Second, despite these recent status gains, women are still the less powerful sex (see Eagly and Wood, 1999; Lamont and Molnár, 2002). Thus, women may show a stronger interest in consuming for status as a means for redressing, at least to some extent, the balance of power (Alderson et al., 2007). Third, as a result of women's increasing entry into male-dominated higher-status occupations and the need to 
ascertain their authority in masculine work environments, they may seek to make status claims by consuming more status markers. Last but not least, women's "status work" extends from the public domain to the family's private sphere, where women are responsible for the status production and status presentation of the household (Collins, 1992).

The lack of clear direction in the relationship between gender and preference for status symbolism does not provide sufficient grounds for formulating a directional hypothesis. Therefore, the following null hypothesis is proposed:

H5: There is no significant difference between male and female consumers regarding their preference for the status meaning of clothing.

\section{Gender and Actual Purchase Behaviour towards Clothing}

Given that women more than men value clothing for constructing and expressing their selfconcept, as well as that self-construction and self-expression is an ongoing process (Giddens, 1992), which involves a continual use of new symbolic resources, female consumers may need a wardrobe with more and varied clothing items. Besides, as a result of the frequent releases of the ever more enticing new fashion styles, female consumers may feel stronger pressures to buy new fashions to reinforce a unique self-image or to stay competitive vis-àvis other females. Also, as discussed above, clothing purchases are a greater source of hedonic pleasures and a mood management tool for female than male consumers. Thus, relative to men, women will likely be more active clothing shoppers. Consistent with this notion, women tend to be earlier adopters, whereas men later adopters of new fashions (Beaudoin et al., 2003), and are bigger spenders on new fashions than men (Goldsmith et al., 1987; Peluchette et al., 2006). Besides, they shop more often for clothes (Chen-Yu and 
Seock, 2002; Mintel, 2010) and spend more on apparel than men (Mintel, 2011; Peluchette et al., 2006). Thus, the following hypotheses are proposed:

H6: Relative to men, women (a) visit clothing shops more frequently to see the new arrivals, (b) make more frequent clothing purchases, and (c) spend more money on clothing.

H7: Relative to men, women buy a more diverse set of clothing types.

The gender effects discussed above are presented in Figure 1.

[Figure 1 here]

\section{RESEARCH METHOD}

\section{Procedure}

The study is based on a cross-sectional survey in the Czech Republic, conducted by an international market research agency through face-to-face home-based interviews in 195 geographic sampling units spread throughout the country. Quota sampling was used with five quota controls (i.e., administrative region, locality size, gender, age, and education). Random selection procedures were applied during all but the final stage of sample selection. The interviewers' assignments contained three quota controls: sex (male and female), age (18-24, 25-29, 30-34, 35-39, 40-44, 45-49, and 50-55), and educational level (primary, secondary/high school, and university). One member of the household meeting the assignment requirements was selected to be interviewed. The interviewers explained the purpose of their visit, guaranteed the complete anonymity of respondents' personal data, read the questions and recorded the respondents' answers. During the interview particular care was taken to ensure that there was no interference from other household members or other persons. The response rate (total interviews as a percentage of total interviews plus refusals) 
was $60 \%$. The number of usable questionnaires was 1,059 . The questionnaire was designed in English followed by translation in Czech-it was validated by back and parallel translation (from a third language) procedures (Craig and Douglas, 2000).

The sample composition is: gender-50.3\% men vs. 49.7\% women; age-18-24 (21.5\%), 25-34 (29.2\%), 35-44 (20.4\%), and 45-55 (28.9\%); marital status—single (28.7\%), married $(60.9 \%)$, divorced $(8.7 \%)$, and widowed (1.7\%); education levels - primary and lower secondary (32.6\%), upper secondary (56.9\%), and university (10.5\%).

\section{Measures}

Respondents' gender was recorded during the survey as male or female. In the consumer behaviour literature gender and sex are often used interchangeably. Before 1989 in the Czech Republic, as well as in the other countries of Central and Eastern Europe (CEE), gender did not exist as a concept distinct from sex. In CEE sex and socio-culturally conditioned gender were, and still continue to be, closely linked. It is noteworthy that in the majority of existing consumer behaviour studies the recorded biological sex of the respondents stands for gender. What is more, several studies report biological sex to be a better predictor of consumer attitudes and behaviour than gender identity (see Palan, 2001).

Consumer interest in clothing captures the attention, concern and curiosity a person has about his/her own clothing, which find expression in the amount of time, energy and money one is ready to spend on clothing (Gurel, 1974, p. 12). The construct was measured with seven items drawn from Gutman and Mills' (1982) Fashion Interest Factor (e.g., I spend a lot of money on clothes and accessories), Schrank and Gilmore's (1973) Clothing Interest Inventory (e.g., The subject of clothing is uninteresting to me (reverse-coded)), and Rosenfeld and Plax's (1977) Clothing Consciousness Factor (e.g., I like to dress elegantly, and I usually spend a lot of time doing so). Two additional items (i.e., I often daydream about 
buying new clothes; I save on other expenses in order to buy clothes) were included based on the first author's first-hand observations and experiences with the Czech marketplace. Respondents' answers were recorded on a five-point Likert scale: 1 (strongly disagree) to 5 (strongly agree).

Preference for clothing symbolic and hedonic meanings taps into consumers' propensity to focus on diverse symbolic meanings and sensory experiences engendered by clothing artefacts (Mittal, 1988). Consumer preferences for clothing's self-symbolic, status-symbolic and hedonic meanings were measured partly with items adapted to the context of clothing as a product category from Mittal's (1988) expressiveness scale. Three items captured preference for self-expressive meaning (e.g., The clothes that I would buy have to be something that helps me express my personality; The clothes that I would buy have to be most compatible with the image I have of myself), two items tapped into hedonic experiences (i.e., The clothes that I would buy have to be something that puts me in good mood when I wear it; The clothes that I would buy have to be something that feels pleasant to my senses (for the eyes, on touching)), and six items measured preference for status meaning (e.g., The clothes that I would buy have to be socially prestigious; The clothes that I would buy have to be expensive brands). A three-item scale derived from Bearden et al.'s (1989) items, which tap into referents' identification through consumption, and adapted to the clothing context of this study were used to capture preference for affiliation meaning (e.g., I often identify with other people by purchasing the same clothing brands they purchase; The clothes I purchase are like those my friends are wearing). Again, respondents' answers were measured on a fivepoint Likert scale: 1 (strongly disagree) to 5 (strongly agree).

Actual purchase behaviour was measured using three single-item scales. Frequency of visits to clothing shops to see whether they have received something new was recorded on an eight-point scale: 1 "Several times a week" to 8 "Once in more than a year" (reverse-coded). 
Frequency of clothing purchases for oneself was recorded on an eight-point scale: 1 "Once a week" to 8 "Once in more than three years" (reverse-coded). Finally, clothing spending was captured by the question: "Would you tell me approximately how much money have you spent on clothes for yourself since the beginning of this year?" This question captures consumer spending on clothing for nearly one-year period, as the data collection took place during the two weeks immediately prior to the Christmas festive season. The rationale for using this question, instead of an alternative one referring to a 12-month period, was to improve recall of factual information.

The information on the types of clothes bought during the same period came from respondents' answers to the following question: "Since the beginning of this year, have you bought for yourself personally any of the following things: Formal wear/party/evening dress, Casual clothes, Sports clothes, Leather clothes, or None of the listed.” After reading these options, the interviewer also read the following statement: "Please note that the question is not about underwear, but about outer clothes such as coats, raincoats, mackintoshes, jackets, suits, trousers, blouses/shirts, knitted clothes (sweaters, cardigans), (for men) ties, (for women) skirts, dresses."

\section{Scales' Reliability and Validity}

The psychometric properties of the composite scales were checked with Confirmatory Factor Analysis (CFA). The fit of the measurement model, which included consumer interest in clothing, and preference for self-expressive, hedonic, status, and affiliation meanings' constructs, was: $\mathrm{chi}^{2} / \mathrm{df}=6.74, \mathrm{GFI}=0.88, \mathrm{CFI}=0.90, \mathrm{RMSEA}=0.07$. The fit of all twofactor models was better than that of the one-factor models. However, the self-expressive and hedonic factors were highly correlated (0.91). In line with Mittal (1988), these two factors were merged in the consequent analysis. In addition, one item from the affiliation measure 
cross-loaded above 0.30 on the status meaning measure and subsequently was deleted. Deleting this item reduced the number of indicators of preference for affiliation meaning to two and resulted in a model with an inadmissible solution. This solution was due to the affiliation meaning factor; hence, it was deleted from the measurement model in order to establish the validity of the other measures. The fit of the revised model was: $\mathrm{chi}^{2} / \mathrm{df}=7.30$, $\mathrm{GFI}=0.89, \mathrm{CFI}=0.91$, and $\mathrm{RMSEA}=0.08 . \mathrm{RMSEA}$ below 0.10 indicates a reasonable fit between model and data (see Fan et al., 1999). CFI value of 0.91 also indicates a satisfactory model fit. GFI "is analogous to a squared multiple correlation in that it indicates the proportion of the observed covariances explained by the model-implied covariances" (Kline, 1998, p. 128); thus, it is amongst the reported model fit statistics. All factor loadings were above 0.5 and significant at the 0.001 level. Besides, all construct reliabilities were above 0.70: clothing interest (0.86), preference for self-expressive/hedonic meanings (0.87), and preference for status meaning (0.84). The reliability of preference for affiliation meaning was assessed with Cronbach's alpha (0.57). This reliability figure dropped from 0.65 after deleting the cross-loading item. As preference for affiliation meaning is an important aspect of symbolic consumption and its reliability score is still above 0.5 , it was retained for further analysis. The average variance extracted (AVE) statistics of the composite measures included in the revised measurement model are: consumer interest in clothing (0.41); preference for self-expressive/hedonic meanings (0.57); and preferences for status meaning (0.47) (see Fornell and Larcker, 1981). Although two of the AVE values are below the 0.5 threshold, they are not considerably below it, which has been argued to be quite conservative and difficult to attain by many studies (e.g., Hatcher, 1994, p. 331). The above results indicate convergent validity of the constructs. As to the constructs' discriminant validity, two of the three AVE statistics were higher than the square of the correlations between any two latent constructs. The square of the correlation between consumer interest in clothing and 
preference for status meaning (0.59) was higher than their AVE values, but this was due to a conceptual relationship rather than to an overlap between the two constructs. Taking also into consideration that the fit of the two-factor models was better than that of the one-factor models, support for the discriminant validity of the constructs was found (see Hair et al., 2006).

\section{STUDY RESULTS}

Hypotheses H1-H6 were tested with multivariate analysis of variance (MANOVA), followed by analysis of variance (ANOVA) tests. SPSS 22 was used for the analysis. Bonferroni confidence interval adjustment with the overall alpha level set at 0.05 was applied to account for multiple comparisons. Multiple-group structural equation modelling (SEM) was not suitable due to the two indicators of preference for affiliation meaning. The multivariate $F$ value for Hotelling's Trace test was significant at the 0.001 level $(F(7,1051)=78.70)$. All but one univariate tests were significant at the 0.05 level or better, thus indicating significant mean differences. Constructs' means and standard deviations on the two genders are presented in Table 1.

[Table 1 here]

For $\mathrm{H} 7$, the distributions of the responses between the two genders on the different types of clothes, which they had bought since the beginning of the year, were examined (see Table 2).

[Table 2 here]

Regarding H1, which posits that female consumers have a stronger interest in clothing than their male counterparts, the univariate results provided support for this hypothesis: $F(1$, $1057)=258.51, p<0.001 . \mathrm{H} 2$ and $\mathrm{H} 3$ were tested simultaneously due to the merger of preference for self-expressive and hedonic meanings' factors. Consistent with the two 
hypotheses, women scored significantly higher on preference for self-expressive/hedonic meanings than men: $F(1,1057)=27.64, p<0.001$. According to $\mathrm{H} 4$, male and female consumers have similar preferences for the affiliation meaning of clothing. This hypothesis was also supported: $F(1,1057)=0.97, p=0.33$. H5 anticipated that male and female consumers have similar preferences for the status meaning of clothing. This hypothesis was not supported: $F(1,1057)=17.52, p<0.001$. Regarding H6, as expected, relative to women men reported: (a) less frequent visits to clothing shops to see the new arrivals: $F(1,1057)=$ 291.94, $p<0.001$; (b) less frequent clothing purchases: $F(1,1057)=105.14, p<0.001$; and (c) spending less money on clothing: $F(1,1057)=4.63, p<0.05$. Hypothesis $\mathrm{H} 7$, stating that women buy a more diverse set of clothing types than men, was also supported (see Table 2).

\section{DISCUSSION}

The present study examined the effects of gender on consumer interest in clothing, preferences for self/social-symbolic and hedonic meanings of clothing, and actual purchase behaviour. All but one hypothesised effects were confirmed, which underscore the important role of gender in explaining consumer symbolic and hedonic preferences and actual clothing consumption. Consistent with the thesis about the more central role of physical appearance in women's than men's self-definition and existing empirical evidence (e.g., Peluchette et al., 2006), women showed a stronger interest in the clothing product category.

In line with prior expectation, women showed a stronger preference for expressing a more unique self-image, as well as for the hedonic pleasures engendered by clothing artefacts than men. Self-expressive clothing symbolism is instrumental for achieving diverse goals, such as increased social popularity, standing out from the female competition, or finding the right partner. Women's stronger preference for the hedonic meaning of clothing draws from the 
higher aesthetic qualities, greater variety, and higher emotional value of female than male clothing.

Similar preference between the two genders was found only with regard to clothing affiliation symbolism. This is an interesting finding, which is in line with one of the competing theories discussed in the literature review, namely, that men and women are equally driven by the need to belong, and as a result show a similar preference for the affiliation meaning of clothing.

As to the relationship between gender and preference for clothing status symbolism, the study findings indicate women's stronger preference for this social-symbolic meaning. Apparently, stronger and/or more diverse social-psychological influences on women with regard to their status in society (e.g., the need to redress gender imbalances in status and power, to ascertain authority in male-dominated higher-status occupations) are likely to be driving female consumers' yearnings for status clothing.

Last but not least, consistent with theory and evidence (e.g., Peluchette et al., 2006), relative to men, women visited clothing shops more frequently to see the new arrivals, made more frequent clothing purchases, and spent more money on clothing. They also bought a more diverse set of clothing types than male consumers, which is underpinned by the former stronger interest in clothing and its use for image- and mood-enhancement purposes, as well as for establishing a stronger competitive position vis-à-vis other female rivals in the dating and mating marketplace. Females' possession of a wider assortment of clothing is in accord with their higher frequency of clothing purchases and spending relative to male consumers. It is of note that formal/party/evening wear notably features amongst female clothing purchases, which is consistent with this study finding regarding female consumers' stronger preference for clothing status symbolism compared with their male counterparts. 
The present study was guided by propositions derived from theories developed in advanced market economies. The context of the present study is the Czech Republic, a newly established Central European market economy, which embraced market reforms in 1989. The fact that the study hypotheses were confirmed (with only one exception) indicates the usefulness of these theories for explaining gender effects on consumers' preferences and actual clothing consumption in general, and in the Czech Republic in particular. The confirmed gender effects might be even more pronounced in the Czech Republic (and in CEE as a whole) than in the countries from the West. This is due to the generally poor clothing choices and the limited access to symbolic and hedonic resources for self-expression, selfenhancement, group identification and self-gratification under the communist rule. The new market realities after the introduction of market reforms offered the freedom of choice and expression, which together with the proliferation of Western style advertising, fuelled insatiable desires and consumption of clothing artefacts (Millan and Mittal, 2010).

\section{MANAGERIAL IMPLICATIONS AND DIRECTIONS FOR FUTURE RESEARCH}

The study's findings underscore the importance of gender for explaining clothing-related consumer behaviour, as well as for segmenting consumer markets with regard to the clothing product category. Specifically, our findings indicate that women are still the more attractive target market for fashion manufacturers and retailers. Women's interest in clothing could be further encouraged by more frequent introductions of new fashions. Frequent launches of new fashion styles may also motivate more frequent visits to clothing shops (both online and off-line) and ultimately more clothing purchases. During the last decade a number of fashion marketers have employed such marketing practices, and fast fashion clothing brands (e.g., Zara) have been enjoying popularity worldwide. The present research affirms the shrewdness of this practice. 
Given women's stronger preference for clothing symbolic and hedonic meanings, they can be targeted with different promotional messages. Since value-expressive clothing, namely, clothing which serves symbolic, hedonic, or psycho-social consumption goals (see Mittal, 1988 , p. 505), is particularly attractive to this consumer group, advertising campaigns could draw attention to the novelty and uniqueness of clothing styles on offer, the involvement of popular celebrities in their development and promotion, the high sensory appeal of the garments and their ability to engender positive emotions.

In view of women's stronger interest in acquiring status-symbolic clothing props, statusconscious female consumers can be targeted with market offers emphasising symbolic brand attributes (e.g., reputable brand name, high quality and premium prices, and stylish designs), and/or status benefits such as impressing others and provoking their admiration, and affiliation with attractive social groups. Naturally, the promotional messages should vary depending on the type of clothing marketed. Formal clothing appeals to females' status and achievement needs, party/evening clothing to their needs for uniqueness, selfexpression/enhancement, and to stand out of the female competition, as well as to their need for sensory stimulation and gratification.

Last but not least, to understand better and respond more adequately to consumers' needs and preferences, fashion marketers should consider engaging more actively their female target audience on social media platforms (e.g., Facebook, Twitter). Social media sites are very useful for reaching target consumers with personalised advertisements and promotional deals. They allow keeping target audiences up to date with the latest styles, obtaining instant feedback, timely responding to complaints, creating online brand communities, and spreading a positive word-of-mouth, to mention some key benefits.

Our findings indicate a few venues for future research. Given the competing theoretical explanations and the general lack of research on gender influence on preference for clothing 
status symbolism, additional research could shed further light on this gender effect. This recommendation can be extended to preference for clothing affiliation symbolism, for which no gender differences were found. Comparing the studied gender effects across different cultural contexts (e.g., in advanced vs. emerging market economies) will provide additional evidence about the viability of the theories guiding our hypothesis development and the generalizability of our findings across different cultures.

Acknowledgement: The authors would like to thank the journal editor and the anonymous reviewers for their constructive comments and suggestions. 


\section{REFERENCES}

Alderson, A.S., Junisbai, A. \& Heacock, I. (2007) Social status and cultural consumption in the United States. Poetics, 35, 191-212.

Barnard, M. (2002) Fashion as Communication. Routledge, London.

Baumeister, R.F. \& Leary, M.R. (1995) The need to belong: Desire for interpersonal attachments as a fundamental human motivation. Psychological Bulletin, 117, 497-529.

Baumeister, R.F. \& Sommer, K.L. (1997) What do men want? Gender differences and two spheres of belongingness: Comment on Cross and Madson (1997). Psychological Bulletin, 122, 38-44.

Bearden, W.O., Netemeyer, R.G. \& Teel, J.E. (1989) Measurement of consumer susceptibility to interpersonal influence. Journal of Consumer Research, 15, 473-481.

Beaudoin, P., Lachance, M.J. \& Robitaille, J. (2003) Fashion innovativeness, fashion diffusion and brand sensitivity among adolescents. Journal of Fashion Marketing and Management, 7, 23-30.

Borgerson, J.L., Schroeder, J.E., Blomberg, B. \& Thorssén, E. (2006) The gay family in the ad: Consumer responses to non-traditional families in marketing communications. Journal of Marketing Management, 22, 955-978.

Browne, B. \& Kaldenberg, D. (1997) Conceptualizing self-monitoring: Links to materialism and product involvement. Journal of Consumer Marketing, 14, 31-44.

Burgess, S.M. \& Steenkamp, J.-B.E.M. (1998) Value priorities and consumer behaviour in a transitional economy: The case of South Africa. Working Paper, Number 166, The William Davidson Institute, The University of Michigan Business School, 1-26.

Burton, S., Netemeyer, R.G. \& Lichtenstein, D.R. (1995) Gender differences for appearancerelated attitudes and behaviours: Implications for consumer welfare. Journal of Public Policy \& Marketing, 13, 60-75.

Buss, D.M. (1999) Evolutionary Psychology: The New Science of the Mind. Allyn \& Bacon, Boston.

Buss, D.M., Shackelford, T.K., Kirkpatrick, L.A. \& Larsen, R.J. (2001) A half century of mate preferences: The cultural evolution of values. Journal of Marriage and the Family, 63, 491-503.

Cash, T.F., Melnyk, S.E. \& Hrabosky, J.I. (2004) The assessment of body image investment: An extensive revision of the appearance schemas inventory. International Journal of Eating Disorders, 35, 305-316.

Catterall, M. \& Maclaran, P. (2002) Gender perspectives in consumer behaviour: An overview and future directions. The Marketing Review, 2, 405-425.

Chen-Yu, J.H. \& Seock, Y.-K. (2002) Adolescents' clothing purchase motivations, information sources, and store selection criteria: A comparison of male/female and impulse/nonimpulse shoppers. Family and Consumer Sciences Research Journal, 31, 5077.

Coley, A. \& Burgess, B. (2003) Gender differences in cognitive and affective impulse buying. Journal of Fashion Marketing and Management, 7, 282-295.

Collins, R. (1992) Women and the production of status cultures. In: Cultivating Differences: Symbolic Boundaries and the Making of Inequality (ed. by M. Lamont and M. Fournier), pp. 213-231. University of Chicago Press, Chicago.

Cox, J. \& Dittmar, H. (1995) The functions of clothes and clothing (dis)satisfaction: A gender analysis among British students. Journal of Consumer Policy, 18, 237-265.

Craig, C.S. \& Douglas, S.P. (2000) International Marketing Research. Wiley \& Sons, Chichester, West Sussex. 
Cross, S.E. \& Madson, L. (1997) Models of the self: Self-construals and gender. Psychological Bulletin, 122, 5-37.

Csikszentmihalyi, M. \& Rochberg-Halton, E. (1981) The Meaning of Things: Domestic Symbols and the Self. Cambridge University Press, Cambridge.

Diekman, A.B., Goodfriend, W. \& Goodwin, S. (2004) Dynamic stereotypes of power: Perceived change and stability in gender hierarchies. Sex Roles, 50, 201-215.

Dittmar, H. (1992) The Social Psychology of Material Possessions: To Have is to Be. Harvester Wheatsheaf, Hemel Hempstead.

Douvan, E. \& Gold, M. (1966) Modal patterns in American adolescents. In: Review of Child Development Research (ed. by M. Hoffman and L. Hoffman), pp. 469-528. Russell Sage, New York.

Durvasula, S. \& Lysonski, S. (2008) A double-edged sword: Understanding vanity across cultures. The Journal of Consumer Marketing, 25, 230-244.

Eagly, A.H. \& Wood, W. (1999) The origins of sex differences in human behaviour: Evolved dispositions versus social roles. American Psychologist, 54, 408-423.

Eagly, A.H., Wood, W. \& Diekman, A.B. (2000) Social role theory of sex differences and similarities: A current appraisal. In: The Developmental Social Psychology of Gender (ed. by T. Eckes and H.M. Trautner), pp. 123-174. Lawrence Erlbaum Associates Publishers, Mahwah, NJ.

Fan, X., Thompson, B. \& Wang, L. (1999) Effects of sample size, estimation methods, and model specification on structural equation modelling fit indexes. Structural Equation Modelling: A Multidisciplinary Journal, 6, 56-83.

Feingold, A. \& Mazzella, R. (1998) Gender differences in body image are increasing. Psychological Science, 9, 190-195.

Fornell, C. \& Larcker, D.F. (1981) Evaluating structural equation models with unobservable variables and measurement error. Journal of Marketing Research, 18, 39-50.

Franzoi, S.L., Anderson, J. \& Frommelt, S. (1990) Individual differences in men's perceptions of and reactions to thinning hair. Journal of Social Psychology, 130, 209-218.

Geary, D., Vigil, J. \& Byrd-Craven, J. (2004) Evolution of human mate choice. Journal of Sex Research, 41, 27-42.

Giddens, A. (1992) Modernity and Self-identity: Self and Society and the Late Modern Age. Polity, Cambridge.

Goldsmith, R.E., Stith, M.T. \& White, J.D. (1987) Race and sex differences in self identified innovativeness and opinion leadership. Journal of Retailing, 63, 411-425.

Griskevicius, V., Tybur, J.M., Sundie, J.M., Cialdini, R.B., Miller, G.F. \& Kenrick, D.T. (2007) Blatant benevolence and conspicuous consumption: When romantic motives elicit strategic costly signals. Journal of Personality and Social Psychology, 93, 85-102.

Gurel, L.M. (1974) Dimensions of Clothing Interest Based on Factor Analysis of Creekmore's 1968 Clothing Measure, PhD Doctoral Dissertation. University of North Carolina, Greensboro.

Gutman, J. \& Mills, M.K. (1982) Fashion life style, self-concept, shopping orientation, and store patronage: An integrative analysis. Journal of Retailing, 58, 64-86.

Hair, J.F., Black, B., Anderson, R.E., Babin, B.J. \& Tatham, R.L. (2006) Multivariate Data Analysis. Prentice-Hall, Upper Saddle River, New Jersey.

Hatcher, L. (1994) A Step-by-Step Approach to Using the SAS System for Factor Analysis and Structural Equation Modelling. SAS Institute, Cary, NC.

Hirschman, E.C. \& LaBarbera, P.A. (1990) Dimensions of possession importance. Psychology \& Marketing, 7, 215-233. 
Holman, R.H. (1981) Apparel as communication. In: Symbolic Consumer Behaviour (ed. by E.C. Hirschman and M.B. Holbrook), pp. 7-15. Association for Consumer Research, Ann Arbor, MI.

Hosoda, M. \& Coats, G. (2003) The effects of physical attractiveness on job-related outcomes: A meta-analysis of experimental studies. Personnel Psychology, 56, 431-462.

Huberman, B.A., Loch, C.H. \& Önçüler, A. (2004) Status as a valued resource. Social Psychology Quarterly, 67, 103-114.

Kaiser, S.B. (1990) The Social Psychology of Clothing: Symbolic Appearances in Context. Macmillan, New York.

Kaiser, S.B., Freeman, C.M. \& Chandler, J.L. (1993) Favourite clothes and gendered subjectivities: Multiple readings. Studies in Symbolic Interaction, 15, 27-50.

Kline, R.B. (1998) Principles and Practice of Structural Equation Modelling. Guilford Press, New York, London.

Lamont, M. \& Molnár, V. (2002) The study of boundaries in the Social Sciences. Annual Review of Sociology, 28, 167-195.

Langlois, J.H., Kalakanis, L., Rubenstein, A.J., Larson, A., Hallam, M. \& Smoot, M. (2000) Maxims or myths of beauty? A meta-analytic and theoretical review. Psychological Bulletin, 126, 390-423.

Li, N.P. \& Kenrick, D.T. (2006) Sex similarities and differences in preferences for short-term mates: What, whether, and why. Journal of Personality and Social Psychology, 90, 468489.

Macrae, C.N., Stangor, C. \& Hewstone, M. (1996) Stereotypes and Stereotyping. The Guildford Press, New York.

Mangleburg, T.F., Grewal, D. \& Bristol, T. (1997) Socialization, gender, and adolescent's self-reports of their generalized use of product labels. The Journal of Consumer Affairs, 31, 255-279.

Marcus, D.K. \& Miller, R.S. (2003) Sex differences in judgments of physical attractiveness: A social relations analysis. Personality and Social Psychology Bulletin, 29, 325-335.

Markus, H.R. \& Kitayama, S. (1994) The cultural construction of self and emotion: Implications for social behaviour. In: Emotion and Culture: Empirical Studies of Mutual Influence (ed. by S. Kitayama and H.R. Markus), pp. 89-130. American Psychological Association, Washington, DC.

McNeill, L.S. \& Douglas, K. (2011) Retailing masculinity: Gender expectations and social image of male grooming products in New Zealand. Journal of Retailing and Consumer Services, 18, 448-454.

Millan, E.S. \& Mittal, B. (2010) Advertising's new audiences. Journal of Advertising, 39, 8198.

Mintel (2010) Youth fashion - UK - December 2010. Mintel Intelligence, London.

Mintel (2011) Clothing - Western Europe (selected countries) - a snapshot. Mintel Intelligence, London.

Mittal, B. (1988) The role of affective choice mode in the consumer purchase of expressive products. Journal of Economic Psychology, 9, 499-524.

Muth, J.L. \& Cash, T.F. (1997) Body-image attitudes: What difference does gender make? Journal of Applied Social Psychology, 27, 1438-1452.

Netemeyer, R.G., Burton, S. \& Lichtenstein, D.R. (1995) Trait aspects of vanity: Measurement and relevance to consumer behaviour. Journal of Consumer Research, 21, 612-626.

Noble, C.H. \& Walker, B.A. (1997) Exploring the relationships among liminal transitions, symbolic consumption, and the extended self. Psychology \& Marketing, 14, 29-47. 
Noth, W. (1988) The language of commodities: Groundwork for a semiotics of consumer goods. International Journal of Research in Marketing, 4, 173-186.

O'Cass, A. (2004) Fashion clothing consumption: Antecedents and consequences of fashion clothing involvement. European Journal of Marketing, 38, 869-882.

Palan, K.M. (2001) Gender identity in consumer behaviour research: A literature review and research agenda. Academy of Marketing Science Review, 2001, 1-24.

Peluchette, J.V., Karl, K. \& Rust, K. (2006) Dressing to impress: Beliefs and attitudes regarding workplace attire. Journal of Business and Psychology, 21, 45-63.

Piaceniti, M. \& Mailer, G. (2004) Symbolic consumption in teenagers' clothing choices. Journal of Consumer Behaviour, 3, 251-262.

Rabinowitz, V.C. \& Valian, V. (2000) Sex, sex differences, and social behaviour. In: Evolutionary Perspectives on Human Reproductive Behaviour (ed. by P. Moller and D. LeCroy), pp. 196-207. New York Academy of Sciences, New York, NY.

Richins, M.L. (1994) Valuing things: The public and private meanings of possessions. Journal of Consumer Research, 21, 504-521.

Richins, M.L. \& Dawson, S. (1992) A consumer values orientation for materialism and its measurement: Scale development and validation. Journal of Consumer Research, 19, 303-316.

Rosenfeld, L.B. \& Plax, T.G. (1977) Clothing as communication. Journal of Communication, 27, 24-31.

Spence, J.T. (1993) Gender-related traits and gender ideology: Evidence for a multifactorial theory. Journal of Personality and Social Psychology, 64, 624-635.

Schrank, H.L. \& Gilmore, D.L. (1973) Correlates of fashion leadership: Implications for fashion process theory. The Sociological Quarterly, 14, 534-543.

Thompson, C.J. \& Haytko, D.L. (1997) Speaking of fashion: Consumers' uses of fashion discourses and the appropriation of countervailing cultural meanings. Journal of Consumer Research, 24, 15-28.

Veblen, T. (1899) The Theory of The Leisure Class: An Economic Study of Institutions. Unwin Books, reprinted New York: Dover Publications, 1994, London.

Wallendorf, M. \& Arnould, E.J. (1988) "My favourite things": A cross-cultural inquiry into object attachment, possessiveness, and social linkage. Journal of Consumer Research, 14, 531-547.

Weber, S., Lynes, J. \& Young, S.B. (2017) Fashion interest as a driver for consumer textile waste management: Reuse, recycle or disposal. International Journal of Consumer Studies, 41, 207-215.

Wee, T.T.T. \& Ming, M.C.H. (2003) Leveraging on symbolic values and meanings in branding. Brand Management, 10, 208-218.

Wang, P.Z. \& Waller, D.S. (2006) Measuring consumer vanity: A cross-cultural validation. Psychology \& Marketing, 23, 665-687.

Workman, J.E. (2010) Fashion consumer groups, gender, and need for touch. Clothing and Textiles Research Journal, 28, 126-139.

Workman, J.E. \& Lee, S.-H. (2011) Vanity and public self-consciousness: A comparison of fashion consumer groups and gender. International Journal of Consumer Studies, 35, 307-315.

Workman, J.E. \& Studak, C.M. (2006) Fashion consumers and fashion problem recognition style. International Journal of Consumer Studies, 30, 75-84.

Worstall, T. (2016) Why Do Retailers Charge Women More Than Men? Because They Can. Forbes, Jan 20, 2016, https://www.forbes.com/sites/timworstall/2016/01/20/why-doretailers-charge-women-more-than-men-because-they-can/\#5ace91c12a6e, accessed on Dec 20, 2017. 
Table 1. Means and Standard Deviations (SD) of Study Constructs

\begin{tabular}{|c|c|c|c|c|}
\hline Construct & Gender & Mean & SD & $\mathbf{N}$ \\
\hline \multirow{2}{*}{ Consumer interest in clothing } & Male & 2.41 & 0.841 & 533 \\
\hline & Female & 3.21 & 0.764 & 526 \\
\hline \multirow{2}{*}{$\begin{array}{l}\text { Preference for self-expressive } \\
\text { /hedonic meanings of clothing }\end{array}$} & Male & 3.90 & 0.652 & 533 \\
\hline & Female & 4.11 & 0.610 & 526 \\
\hline \multirow{2}{*}{$\begin{array}{l}\text { Preference for affiliation } \\
\text { meaning of clothing }\end{array}$} & Male & 2.55 & 0.808 & 533 \\
\hline & Female & 2.50 & 0.864 & 526 \\
\hline \multirow{2}{*}{$\begin{array}{l}\text { Preference for status meaning of } \\
\text { clothing }\end{array}$} & Male & 2.67 & 0.843 & 533 \\
\hline & Female & 2.88 & 0.821 & 526 \\
\hline \multirow{2}{*}{$\begin{array}{l}\text { Frequency of shops' visits to see } \\
\text { new arrivals }\end{array}$} & Male & $\begin{array}{r}4.02 \\
\text { (Once in } 3 \text { months) }\end{array}$ & 1.517 & 533 \\
\hline & Female & $\begin{array}{r}5.52 \\
\text { (Twice a month) }\end{array}$ & 1.333 & 526 \\
\hline \multirow{2}{*}{ Frequency of clothing purchases } & Male & $\begin{array}{r}5.50 \\
\text { (Once in } 6 \text { months) }\end{array}$ & 0.965 & 533 \\
\hline & Female & $\begin{array}{r}6.09 \\
\text { (Once in } 3 \text { months) }\end{array}$ & 0.901 & 526 \\
\hline \multirow{2}{*}{ Money spent on clothing } & Male & $\begin{array}{r}3.42 \\
(4.001-6.000 \mathrm{Kc \breve {c }})\end{array}$ & 1.763 & 533 \\
\hline & Female & $\begin{array}{r}3.66 \\
(6.001-9.000 \mathrm{Kc \check {c }})\end{array}$ & 1.858 & 526 \\
\hline
\end{tabular}


Table 2. Types of Purchased Clothing by Gender

\begin{tabular}{|lccccccc}
\hline Gender & $\begin{array}{c}\text { Formal, } \\
\text { Casual, } \\
\text { Sports, } \\
\text { \& }\end{array}$ & $\begin{array}{c}\text { Formal, } \\
\text { Casual, }\end{array}$ & $\begin{array}{c}\text { Formal } \\
\text { \& Sports } \\
\text { Casual }\end{array}$ & $\begin{array}{c}\text { Formal, } \\
\text { Sports, } \\
\text { \& } \\
\text { Leather }\end{array}$ & $\begin{array}{c}\text { Casual, } \\
\text { Sports, } \\
\text { \& } \\
\text { Leather }\end{array}$ & $\begin{array}{c}\text { Casual } \\
\text { \& } \\
\text { Sports }\end{array}$ & $\begin{array}{c}\text { Sports, } \\
\text { \& } \\
\text { Leather }\end{array}$ \\
\hline Male respondents (\%) & 34.48 & 41.42 & 36.89 & 39.39 & 50.00 & 48.24 & 54.22 \\
Female respondents $(\%)$ & 65.52 & 58.58 & 63.11 & 60.61 & 50.00 & 51.76 & 45.78 \\
\hline
\end{tabular}


Figure 1. Hypothesised Gender Effects
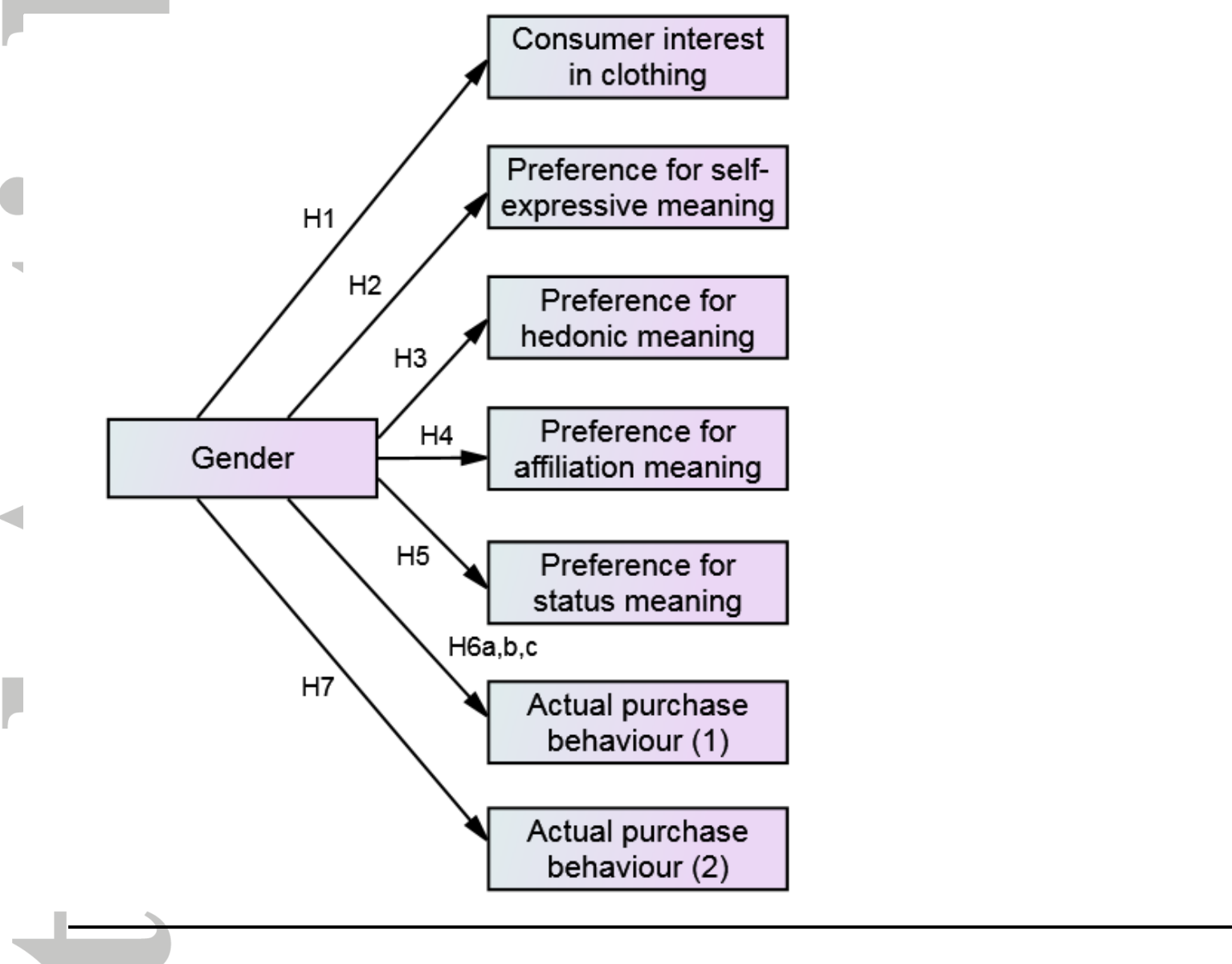